\title{
Racism in the 21st Century: Debbie Tucker Green's Eye for Ear
}

\author{
Belgin Bağırlar
}

Department of English Language Teaching, Aydın Adnan Menderes University, Turkey

\section{ARTICLE INFO}

Keywords:

Contemporary Theatre

Stuart Hall

Violence

Racism

\begin{abstract}
Does equality exist in the 21st century, or, are minorities still forced to fight for equality? In nineteenth century, Britain, racism was blatant in all spheres of cultural, social, and economic life to the point that it crossed over into literature and theatre. In 1978, UNESCO adopted the Universal Declaration of Human Rights. Forty years have since passed, but has it made any difference? Contemporary British playwright Debbie Tucker Green's Eye for Ear (2018), staged at the Royal Court Theatre, reminds us that racism and inequality is still a key social-political issue. This threeact, avant-garde, colloquial play depicts how both AfricanAmericans as well as Black British people still live with racism today. It also highlights racism's linguistic and legal past. Tucker Green particularly focuses on the violent aspect of that racism through the lens of different characters: an academic, a black student, a black boy, and black parents. The play concludes with crushed hope, for it deduces that Caucasians both in the United States and in Great Britain still dominate practically every facet of society. This study will examine Green's Ear for Eye, racial discrimination in the $21^{\text {st }}$ century, and how Tucker Green projects her views upon her work through the theory of race and racism.
\end{abstract}

\section{Introduction}

How far have we come regarding racism since the eighteenth century? Are we still not living in a world watching George Floy or Mark Duggan being killed by the police? Of course, blacks have gained some political rights, and we can hear their resistant cries against racism. Nevertheless, it is quite apparent that these developments are not enough in the twenty-first century.

In an academic context, although the studies on racism are quite limited, a sense of vividness appears in Black British theatre from the 1980s onwards. According Peacock (2008) and Davis (2006), Black British playwrights are divided into two groups, as they deal with different topics before and after the 1990s. First generation playwrights such as Jacqueline Rudet, Caryl Phillips and Winsome Pinnock, mostly reflect their commitment to their roots and their culture, while Roy Williams, Debbie Tucker Green, Dona Daley and Jackie Kay, belong to the second generation, "have produced new narratives of identity, gender, sexuality and nationality" (Peacock, 2008, p. 48). A woman of Black British heritage herself, Debbie Tucker Green (intentionally written in lowercase letters) has contributed much to Black British theatre with her experiential style. The aim of this article is to both explore how Debbie Tucker Green reflects racism in the USA and the UK in Eye for Ear, as well as to comprehend her point of view on racism within the framework of Stuart Hall's views.

green's plays explicitly intertwine with Black culture. Her skills got her promptly noticed in Black British theatre through plays such as dirty butterfly (green, 2003) and born bad (green,

* Corresponding author E-mail address: belgin.bagirlar@adu.edu.tr 
2003). Dealing with sexual harassment and violence in both, she becomes the centre of attention of feminist critics through the theme of female sexuality in trade (green, 2005a) and generations (green, 2005a). In stoning mary (green, 2005b), she humorously exposes brutality in non-European culture by using white actors. Staged at the Royal Court Theatre, both random (green, 2008) and truth and reconciliation (green, 2014) explore multiple dimensions of violence. Thus, green reveals her creativity by introducing her audience to sexual abuse, violence, sex tourism, and incest.

She presents her superior use of language to her audience with word games, poetic phrases, metaphors, and repetition. She reduces her characters down to general terms like dad, girl, mum, and child, rather than giving them proper names, and in doing that, makes her work universal. In addition, writing her name, she prefers to use lowercase letters and this obviously makes her more noticeable. green's plays are often open-ended, and are like puzzles. She does not allow her audience to follow the topic in a certain order. The audience has to try and make sense out of fragmented scenes. It is only at the end of the play it becomes clear who mary is in stoning mary and why she deserves such a severe punishment. ear for eye (green, 2018) contains independent scenes by virtue of green's direct and urgent language, and use of violence in her plots; Ken Urban likens her style to Sarah Kane. However, green quite loudly and clearly rejects this similarity. She mentions that "The influences for me are people like the Jamaican poet Louise Bennett - and music, particularly songwriters such as Jill Scott and Lauryn Hill" (Gardner, 2005). Goddard (2007) also draws attention to the traces of black culture in green's plays and asserts "it is equally imperative to understand black women's work within traditions of black cultural production, and Tucker Green locates her main inspirations as coming from black music, poetry and performance" ( $\mathrm{p}$. 185). In this sense, when we examine green's ethnic language and themes, we come across the traces of her ancestral African culture.

\section{Literature Review}

\section{Stuart Hall and Racism}

The UK saw a massive influx of immigration after the 1950s, so immigrants struggle to adapt to the dominant culture has started. People of Caribbean and African descent who had migrated to the USA and the UK, both in search of better living conditions as well as a better education, played - and still play - a fundamental role in the regeneration of Britain. Thus, "Black people became the scapegoats for the economic and social failures of the British political system whereby the alien cultures of the blacks are seen as either the cause or else the most visible symptom of the destruction of the British way of life" (Pearce, 2013, p. 14).

A contemporary theorist, Stuart Hall examines what causes racism in detail from various angles. Hall founded the Centre for Contemporary Cultural Studies in 1964, and pioneered the development of cultural studies. Helen Davis (2004) asserts that "Hall takes as his main thesis the uneven patterns of progress, change and stability within the physical environment of working-class Londoners" (p. 12). In this regard, traces of Marxism can be found in Hall's theory of racism as well. According to Hall (2017),

Race is a discourse; that it operates like a language, like a sliding signifier; that its signifiers reference not genetically established facts but the systems of meaning that have come to be fixed in the classifications of culture; and that those meanings have real effects not because of some truth that inheres in their scientific classification but because of the will to power and the regime of truth that are instituted in the shifting relations of discourse that such meanings establish with our concepts and ideas. (p. 45). 
Hall argues that racism is the substantial and main reason for class division among people. Class discrimination has existed throughout the world for centuries, and is "a system of meaning" that is undoubtedly powerful. 'A system of meaning' is hard to comprehend because it is located in every area of our lives and guides our ideas. First, as stated by WEB Du Bois, "race is not a scientific - that is, biological-concept" (Hall, 2017, p. 37). Hall believes that we all have certain natural physical abilities, organs, and even 'common blood'; therefore, racism is not scientific but rather biological, due different skin tones and hair styles (i.e., "signifiers of difference"). Frantz Fanon shares a similar view with Hall and Du Bois, and calls the definition and shaping of these physical differences by whites as "epidermalisation," or "the inscription of racial difference on the skin" (Hall, 2017, p. 62). By the same token, Hall (2017) advocates that "race exists only in discourse" (p. 49), hence why "it is a self-referential, autonomous belief system in that it cannot be tested in any way against the reality of the world of human diversity "(p. 49). We, however, have to consider that language is an entrenched and a powerful system. Lastly, Hall (2017) deems that "material differences of all sorts in the world" (p. 50) play a vital role in race. The harder it is to deny material differences, the harder it is to reject the concept of racism that exists in the world, considering that racial difference feeds on it. Whites associate all good materials with themselves, while associating bad and unusable materials with "the others". In this way, it provides perceptual, economic and political benefits.

Hall highlights how a white boy react seeing a black man in Fanon's Black Skin, in White Masks book. The child says "Look, a Negro! ... Mama, see the Negro. I'm frightened" (Hall, 2017, p. 70). Does the child have this horror fantasy, negro object, congenital? Or was the negro object taught to him by his family? Hall (2017) notices the absolute existence of this negro object in our relationships and world politics, and advocates that "the objects of psychic fantasy in our subjective lives as in our institutional lives and everyday social practices" (p. 71). Although Hall considers the concept of racism to be abstract, he does not deny that 'racial classification systems' have a history. In his view, racial classification systems started in the 1400s with Europe's first encounter with the New World. This history also shows how racism and racial systems have survived well into the present day. By the same token, "this is the historical moment when what Mary Louise Pratt has called the great Euro-imperial encounter with difference" (Hall, 2017, p. 53). Thus, the century's old system of classifying the human race begins. The system is so powerful and complex that "we are only at the beginning of understanding the complexity of such structures and mechanisms" (Hall, 2017, p. 71).

\section{Findings}

Are these true men? Do they belong to the same species as us? Or are they born of another creation? (Hall, 2017, p.54)

Green's outstanding play staged at Royal Court Theatre in 2018 and directed by green. With no special protagonist, green refers to a large group of people since her play consists of African Americans, Black British people, a Caucasian academic and an African American. The play reflects her innovative style and critical perspective of racism. Focusing on her universality and cruelty, Adiseshiah (2020) depicts that her play "dramatizes with shattering boldness the lack of progress made with respect to racial equality since the horrors of slavery and racial segregation in nineteenth - and twentieth-century southern United States" (p. 1-2). green brings to light the cruel racism in both British and American society with all her frankness.

According to Pearce (2013), black people have no chance against their white contemporaries. Since, "Black people were defined as alien / other and a threat to the values that Englishness 
represented" (p. 14). green uncovers many times throughout the play that black people are perceived by white people as an enemy that must be destroyed. The first scene begins with a jarring conversation between an African American mother and her son. She tries to explain that any action against the police will be perceived negatively, therefore he lays out a series of options to solve his weird situation. The speeches of Son, who is looking for and answer and Mother, who tries to explain that whatever Son does will not work, are quite remarkable:

SON If I left them down?

MOM Belligerent.

SON by my side-?

MOM Attitude.

SON (Hands) in pockets?

MOM Concealing.

SON Jacket pockets -

MOM obscuring

SON pants pockets -

MOM cocky

SON hands together -?

MOM Masking (green, 2018, p. 2)

None of the options Son offers work. He cannot find a way out. In this way, Debbie emphasizes that all black actions taken in front of the white power have negative connotations. In this case, the fixed stance of black people, and even their very existence, is negative in and of itself. Overflowing with the desire to adapt to white culture, Son embodies hybridisation.

On the other hand, first generation African Americans or Black British people are closely tied to their roots. Anderson (1991) asserts "Seen as both a historical fatality and as a community imagined through language, the nation presents itself as simultaneously open and closed" ( $p$. 146). Despite having acquired British citizenship, they attach prominence to their common cultural and historical values. green indicates their attitudes with the impressive speeches of African American young woman and Older woman in the second scene. green spells Older Woman as (WO)MAN, implying that the words of the character belong to all African Americans, regardless of what gender they are. The older woman also expresses a sense of nostalgia:

Older Wo (man) ... Before the dogs spat

And the pigs barked

And the people spat

And the dogs barked

Before hateful eyes

More hate-filled

Than mouths - and mouths which

Overflowing with their...

When actions

Were actively

Violent

Violently violating us 
And inaction was

Violent

Violently violating us

Hate-filled,

Hate fueled. Driven.

Before our children had

No chance (green, 2018, p. 14)

Older Woman claims that 'not only she but also they were here' before economics and technology improved, before politics, before people hated each other and inflicted violence on each other. green mentions that African Americans have a long history, and that they have existed since the dawn of man itself. Young Adult also supports Adult, stressing the fact that this is not a competition. Hence, according to green, old black people represent the 'closed' community, while young adult presents image of the 'open' community. green reunites her audience through Young Adult. Young Adult sets forth that he worked hard throughout his school life, and learned how clouds formed while his friends played outside. Green also refutes the argument that black people are an uneducated population. Young Adult, who is knowledge in many subjects, begins to perceive racism better as he learns. With a desire to resist, he participates in protests against racism. Nevertheless, "tear gas is a motherfucker" (green, 2018, p. 93), it is bored of those who walk for freedom. green uses a discerning as well as well-educated character of the Young Adult activist to justify the protest, but their action still fails. Young Adult exclaims 'this world ain't theirs' (green, 2018, p. 95), stating that white people are making him feel worse day by day. Nonetheless, although Young Adult is ready to fight for his own right, Adult tries to explain repeatedly that it will not work. Since Young Adult is neither the first nor the last resister. Throughout the play, green refers to Young Adult's aggressive attitude and Adult's calm demeanour. In this sense, the protest that Adult advocates is a peaceful method to express his political view, whilst the rebellion that the young adult wants to start is violent.

The situation is no different for other black British activists who have resisted this injustice. In England, in 1993, a group of racists killed a black teenager named Stephen Lawrence. His family sued the Metropolitan Police Service because the police officers did not conduct the investigation in accordance with the rules of justice. Gilroy (2004) elucidates that after "this racist murder and the negligence of the police were heard by the public, both facist and antiracist demonstrations started" (p. 50). On the other hand, when we recall the Brixton, Chapetown, Handsworth, and Tottenham riots of 1981, we become aware of the green's critical point of view.

She exposes her audience to the brutal reactions towards activist woman, an arrested Black British woman. Just like Son, who tries to find out where to put his hand in the first scene but finds out that his every move poses a threat, the black British woman does not know what to do. During the play, green again mentions Woman, a character, and purports how four policemen squeeze the Woman at the corner and violates her before being arrested. When she demands them to tell her something, they order her to shut up. When she asks a question, they say 'acting aggressive'. Each time they threaten her, warning that her "mouth will get you into trouble so best you shut up" (green, 2018, p. 21).

Green (2018) repeatedly uses antonyms like silent-shout, aggressive-passive, know-not know, start-stop, and defence-threat to get the audience's attention. Through word games, she also reveals the contrast of what is experienced and narrated. Even when Woman deridingly asks them why they chose her, she gets a very meaningful answer, 'fits the description' (p. 21), 
and keeps quiet. The other police officer also argues that the reason for the pressure they exert on black people is their false attitudes.

Gilroy (2004) emphasizes that all negative labels stuck on black people are difficult to remove. He asserts "The historic associations of blackness with infrahumanity, brutality, crime, idleness, excessive threatening fertility, and so on remain undisturbed" (p. 22). Here, green reveals the prejudice about black people settled in the society. All four police officers make fun of Woman; their sarcastic smiles are the indication that the white people still refuse and exclude them. green is aware that institutional racism is a very far-reaching problem. For this reason, institutional racism is ruthlessly enforced, not only against women but also men. In Scene 11, Man was subjected to verbal violence similar to the character of Woman taken from the cell. He uses the black British character to reveal the cruel side of racism. Man cannot understand how to behave like other black characters because:

MAN When they said i was

'bein aggressive'

And I weren't.

And I weren't.

When they said that $\mathrm{i}$ was shouting

When I was speakin.

I was speakin.

When they said $\mathrm{i}$ was actin aggressive

When I never was (green, 2018, p. 94)

Green repeats almost all the conversations of Woman in the second scene. Man does not grasp why he was chosen; six police officers tease Man as well as humiliate him with their sarcastic looks and laughs. Finally, the cops brazenly ask the man to do a striptease. Desperately doing what they ask, Man takes his breath away while depicting his trauma, and avoids telling the end of events. green, thus, using similar sentences and incidents, effectively presents the traumatic events that black people - who have no chance against the racism of the white people - constantly experience and how they suffer. In fact, Green's similar scenes and language are directly proportional to the events that are constantly repeated in real life.

Green, this time, aims to give make her audience see the perspective of other protesters. Two black British friends, Friend1 and Friend2, participate in the protest, and witness the police arrest a woman, Woman, who is also of their race. Friend2, a novice protester, is excited to dare to record the event on camera; according to him, he 'made a difference' (green, 2018, p. 46). However, Friend1, who has been participating in the march protests for two years now, delineates what he saw:

FRIEND 2... 'Move along' complyin with the 'There's nothin to see here' with the 'Switch that off, then it snapped off - it was snapped off, you shut your shit little effort of filmin off as soon as they said... (green, 2018, p. 49).

Green does not remark how old her characters are. However, Friend 2 is more mature than his other friend, and emphasises that his friend actually did nothing. In this scene, green confronts her audience with the facts, stressing how meaningless and ineffective the protests are.

In the second act, green adds a new dimension to her play with a series of events between a male, white American teacher (aka. American male) and female African-American student (aka. African-American female). The student discusses a brutal racial murder with her teacher. Although the student advocates that this massacre has no explanation and that it is not worth being defended, the teacher always has an answer, mentioning that sad reasons 
exist behind the massacre. His father had allegedly abandoned the killer when was only 12 . While this is cited as the main underlying cause of the horrific murder committed by the teacher, the student refutes him by claiming that a 12-year-old boy abandoned by his father is adolescent enough to accept the situation. When African-American female attempts to explain herself, American male always dominates and silences her.

MALE Not eight, twelve -

FEMALE oh.

MALE Which makes

FEMALE right

MALE makes all the difference. He smiles

Female I think aged twelve is old enough to -

MALE you haven't been through what he's been through. (green, 2018, p. 111)

The female student argues that the age of 12 is old enough to deal with certain problems, going as far to claim that the offender's two sisters are 'normal'. Unable to find a word to resist him anymore, American male scolds his black student, explaining that he knows nothing but that he has always researched and questioned everything. He adds that any black student who does not do his/her homework has an excuse, and they generally refuse what they do not know. Female states that she always does her homework and has no such problem. Nevertheless, American male never pays attention to what she says. In this case, green also uncovers how illiterate and reckless the black race is perceived to be by white people. During the dialogue between both characters, green's clever use of word games is quite striking. African American female uses the word 'a boy' to describe the ruthless killer, whilst American male calls the killer 'a male child'. In this case, the phrase is used in a way that it depicts the perpetrator of the murder as being but an innocent child.

Male makes it obvious that he is on the side of the criminal and repeatedly argues in his defence. In addition to the psychological disturbance caused by his father's abandoning him at a young age, Male implies that there may be domestic violence or abuse in their home, suggesting fabricated reasons to justify the murderer's crime. On the other hand, Female claims that there is no domestic violence or abuse.

MALE we don't know what happens behind closed doors - what's 'normal' behind closed doors do we, do we? Not for sure.

FEMALE She's said / no -.

MALE And After years of -

FEMALE the kids said no as well - the sisters I / mean.

MALE and who knows what's said if it was that insidious psychological abuse taking place within that household, nothing 'documented' doesn't mean something doesn't exist. Doesn't mean people are going to be forthcoming doesn't mean it's going to be an easy admit, doesn't mean it's easy to admit that was going on so if they did say nothing or said it didn't, doesn't mean that it did not take place. Does it? ....

FEMALE There wasn't any domestic / abuse

MALE narrowness of thought doesn't help (green, 2018, p. 123-124)

There are mitigating reasons for the crime committed for Male. Although Male tries to find mitigating reasons, Female wishes to emphasise that this is not always true. She does not accept Male's comments, so Male blames her again for being ignorant and lacking in thought. The criminal is not actually a murderous murderer, only "a damaged young man, who did a 
damaging thing" and even just a racist, not a fantasist. (green, 2018, p. 128). Using these characters, Green once again proclaims how black people suffer. Black people are guilty enough to deserve to be murdered by white people.

In the second scene, Female, again, mentions that there were actually two murderers, and that they were responsible killing 120 people, including eighteen children. Male, on the contrary, detects a different defence area, claiming that both people are isolated by their own loneliness and by their surroundings. However, Female rejects this:

MALE 'they' has a large enough social circle someone would stop him-them, or say something or leak something or try to convince so, y'know I think my theory - the theory the studies stand

FEMALE not if their social circle all thought like them. (green, 2018, p. 134)

Thus, green negates another defence of white people. As Male claims, criminals are not asocial. In reverse, as Female points out, nobody warned them about racism. Even though Female says what she deems, Male does not take her seriously. When she squeezes Male and gives difficult answers, Male humiliates and accuses her of being 'emotional'. Female states that she cannot make sense of the two white friends taking up arms and murdering their other black friends at school. Male's answer is quite clear:

MALE they aren't you.

FEMALE I'm just -

MALE they aren't / you.

FEMALE they aren't me but me - we aren't allowed to / be them. (Green, 2018, p. 141)

Female clearly emphasises the inequality between black people and white people. Male, on the contrary, successfully changes the subject and asks Female if she is depressed. green's wordplay and the course of the dialogue both arouse curiosity, as well as leads questions to be raised among in the audience. Female often prefers to remain silent against Male's advocacy; this encourages Male more. Nonetheless, in scene four, the audience actually takes into account Female's short and concise words and becomes acutely aware of female's intelligence. Female is aware of what Male is trying to do from the very beginning; "FEMALE you really do find words for everything. Words for anything"(Green, 2018, p. 150).

Male, on the other hand, cares about neither female's opinion or her words. He simply focuses on the crime committed by the murderer is not 'political', and even argues that the massacre is 'a home-grown heart-breaking tragedy'. From the fourth scene onwards, Male begins to contradict himself because now he has no reason to defend and almost justify the massacre. He concedes that while he initially advocated that the separation of families that are negatively affected the psychology of their children, he did not blame the parents for how they raised the them either. Female makes it explicit that her own families have always been blamed, even criticised for the way they raise their children. In the fifth scene, Male likens criminals to "copy cats". Unable to stand Male's words as soon as she hears Male's analogy, Female becomes more critical of Male. Just as Male refused to help him at the beginning of the game, saying "I'm not here to be / helpful" (green, 2018, p.164) to Male (who said he was not helpful at all), Female does the same. Although Male tries to convince Female that what she says makes sense, she is unable to succeed. Female, with all her courage and frankness, pokes fun at saying that she is tired of Male's nonsensical metaphors and explanations, and that she is even depressed for this reason. In the final scene, Female blames Male and asks why she doesn't plainly accuse the murderers of assassination, racism, and terrorism. "It's 
not," says Male, who doesn't like the Terrorists analogy and he claims that "we're not -..." (green, 2018, p. 165). He clearly expresses that he is trying to protect himself, the murderers, and his race. Moreover, green does not end the conversation here. Although Male says that all his defences from the very beginning are in fact "not really hypocritical at all" (green, 2018, p. 165), he reveals all his hypocrisy. Thus, green evokes deep and intense emotions among her audience.

Green presents the events that happened in the last part of her play with evidence. In the first scene, she brings up the Jim Crow Laws of California, Alabama, and West Virginia that were in place in the 1850s and the 1960s to legally segregate black from white people. The reason why these laws were called Jim Crow is quite meaningful. Jim Crow was a constantly trembling black minstrel show, a kind of drama, a character mocked by white people. Therefore, the character completely reflects how white people viewed black people during that period towards. Gradually, black and white people began to inhabit separate neighbourhoods, receive treatment in separate hospital rooms, board separate buses, play cards in separate halls, dine in separate restaurants, and watch movies from separate sections of the movie theatre. Although people claimed American Supreme Court created these laws to ensure equality, in 1954, they decided not to segregate public schools, a true step taken to ensure equality. green confronts these laws in all their nakedness. The so-called equality rules are actually indicative of racial inequality. green uses a number of actors who retell these laws. The players include family members - mother, father, sister, brother, wife and husband. green declares that the injustices and suffers of black people are actually carried out systematically. In the second scene, she cites The Barbados Slave Codes of 1661-a law that, contrary to its initial aim to protect slaves, was actually about how slaves are to be used, sold, and operated under harsh conditions. "This code, which largely reiterated the language and clauses of the 1661 Barbados slave shaw, was copied throughout the British Windward Islands acquired at the end of the Seven Years War" (Morgan, 2007, p. 114). Slave Codes were enforced in Jamaica in 1664, South Carolina in 1696, and Antigua in 1702; they were legally-codified inequality. It is impossible for the audience not to be horrified as green transmits slave codes to her audience:

GRANDDAUGHTER We forbid slaves from selling sugar cane,

For whatever reason or occasion... at the

Risk of a whipping for the slaves...

We also forbid slaves from selling any type

Of commodities, even fruit, vegetables, firewood, herbs for cooking... (green, 2018, p. 174)

Slaves who do not earn money cannot buy anything for themselves and cannot survive without their masters. In addition, their freedom is not restricted by money alone. Slaves are only allowed to go out once a week, and cannot go far without the permission tickets given to them by their masters. If they do, they will be judged, punished, and stigmatised as attempted escapees. In a way, they stand in barns like animals, waiting for their master to feed and use them. Having their own weapons and even engaging in activities of their own tradition (e.g. blow their horns or shell) is the cause of death and torture for slaves. "The slave who has struck his master in the face or has drawn blood, or has similarly struck the wife of his master, his mistress, or their children, shall be punished by death" (green, 2018, p. 180). green cruelly reveals that slaves were forced to live a miserable life within the possibilities of these unjust laws. The scene ends with a death threat against the slaves. As in the first scene, green uses family members - child, grand dad, mother, dad - to disclose the continuity of inequality. 


\section{Conclusion}

Green deals with racism (a significant political and cultural problem in Ear for Eye) from various angles. Since it features different characters and topics in each scene, the audience needs to combine the pieces: (1) the difficulties of a black family explaining how to treat their child, (2) the identification of black people as thieves, gangs, and savages by white people, (3) disturbing conversations between a white teacher and a black student, (4) a young adult who is overwhelmed by injustice and wants to join the riots, and (5) an adult who argues that protest is the best way to make their voice heard. With all its nakedness, green uncovers racist contempt, and violence that black people have to face. Throughout the play, using similar words and incidents for both men and women, green makes it clear that racist violence applies to all black people, regardless of gender.

The fact that she gives general names to her characters and uses both American-Africans and black British characters expands the target audience of the play. During the play, the inner voices and silences of the characters both create more emotional impact on the audience as well as reveal the realistic side of the play. Almost all of the green's characters have supressed identities. The characters either have difficulty expressing themselves, or opt to be silent.

Considering that racism was first conceptually defined in the 1930s, green's mention of the Jim Crow Laws and Slave Codes point out that the history of racism is deeply rooted. Moreover, bringing these laws to the agenda, green reminds the audience of the violence and injustice they (black people) have experienced, reveals the ugly face of racism, and encourages her audience to question. green, furthermore, suggests that racism is not yet a thing of the past, implying that it has morphed rather than disappeared. Black people have to raise their children according to white morality. She does not offer her audience hope. Ear for Eye reveals green's actual pessimistic view on racism.

\section{References}

Adiseshiah, S., \& Bolton, J. (Eds.). (2020). Debbie Tucker Green: Critical Perspectives. Springer International Publishing AG.

Anderson, B. (1991). Imagined communities: Reflections on the origin and spread of nationalism (rev. ed.). London: Verso.

Davis, G. (2006). Staging new Britain: Aspects of black and South Asian British theatre practice. P.I.E.- Peter Lang.

Davis, H. (2004). Understanding Stuart Hall. Sage.

Gardner, L. (2005, March 30). 'I was messing about'. The Guardian.

Gilroy, P. (2004). After empire: Multiculture or postcolonial melancholia. Routledge.

Goddard, L. (2007). Staging black feminisms: Identity, politics, performance. Springer.

Green, D. T. (2003). dirty butterfly. MIT Press.

Green, D. T. (2005a). Trade and Generations. MIT Press.

Green, D. T. (2005b). stoning mary. MIT Press.

Green, D. T. (2008). random. Nick Hern Books.

Green, D. T. (2013). Born bad. Dramatists Play Service Inc.

Green, D. T. (2014). Truth and Reconciliation. Dramatists Play Service Inc.

Green, D. T. (2018). eye for ear. Nick Hern Books. 
Hall, S. (2017). The Fateful Triangle: Race, Ethnicity, Nation. Harvard University Press.

Morgan, K. (2007). Slavery and the British Empire. Oxford University Press.

Peacock, K. (2008). Black British drama and the politics of identity. In N. Holdsworth \& M. Luckhurst (Eds.), A concise companion to contemporary British and Irish drama, 48-65.

Pearce, M. C. (2013). Black British Theatre: A Transnational Perspective. Phd. Thesis, University of Exeter, January 2013. 